\title{
OBNOVA TEOLOGICKEJ METÓDY V REFLEXII MARCELLA BORDONIHO (1930-2013)*
}

I VA NA K O S T Ú R O VÁ

\section{ABSTRACT \\ Renewal of the theological method in the reflection of Marcello Bordoni (1930-2013)}

A renewal of the theological method in the spirit of the II. Vatican Council represented a significant change in dogmatic theology. It was not just a question of technical nature, but rather a change of the way of thinking and approach. The main purpose of this article is to point out how Marcello Bordoni - an important Italian theologian faced the challenges of the II. Vatican Council. In the first part the article presents the personality and theological works of M. Bordoni. In the second part, it points out the difficulties which the post-conciliar theologian had to face, and consequently discusses the methodological bases that Bordoni considered to be a necessary premise for any authentic theological reflection. Presentation of the Italian theologian and his effort to grasp the theological method is important not only for the theory. The question of the method also reflects the spirituality of the theologian.

\section{Keywords}

Marcello Bordoni; Dogmatic Theology; Theological method; II. Vatican Council; Sacred Scripture; Tradition

DOI: $10.14712 / 23363398.2018 .18$

$\mathrm{M}_{\mathrm{a}}$ arcello Bordoni bol popredným talianskym teológom, ktorý výrazne ovplyvnil vývoj teológie a zvlášt' kristológie po II. vatikánskom koncile v Taliansku.

* Obsah tohto článku je súčastou pripravovanej dizertačnej práce na CMTF v Olomouci. 
Patrí ku generácii teológov formovaných ešte pred koncilom, no svoju činnost' začal až v pokoncilovom období. V tom čase systematická teológia prechádzala podstatnými zmenami, týkajúcimi sa teologickej metódy. ${ }^{1}$ Štúdium teológie absolvoval podla tzv. dogmatickej metódy, ktorá prevládala na teologických fakultách v prvej polovici 20. storočia. Táto metóda odmietala hermeneutické prístupy, ktoré by pripúštali, že l'udské myslenie je historicky podmienené. Dogmatická teológia tak postupne upadala do určitého abstraktizmu kategórií a téz. Chýbalo jej prepojenie so životom, spiritualitou, ako aj so živým odovzdávaním viery. ${ }^{2}$ Daná situácia podnietila mnohých teológov už v predkoncilovom období, aby hl'adali nové teologické prístupy, ktoré by boli schopné vytvárat' prepojenie medzi kultúrou, dejinami a pravdami viery. ${ }^{5}$ Ich náročné úsilie, ktoré bolo často sprevádzané nepochopením vo vnútri Cirkvi, vyvrcholilo obnovou teologickej metódy, ktorá sa presadila na II. vatikánskom koncile. Ide o tzv. „geneticko-progresívnu metódu“, ktorá je načrtnutá v koncilovom dokumente Optatam totius 16.

V tejto súvislosti sa môžeme pýtat: Ako sa systematická teológia dokázala vyrovnat's výzvami, ktoré so sebou priniesol II. vatikánsky koncil? Bola aplikácia geneticko-progresívnej metódy taká jednoznačná? Akým tažkostiam museli jednotliví teológovia čeliț v pokoncilovom období?

Hlavným zámerom tohto príspevku je poukázat', ako sa s výzvami II. vatikánskeho koncilu vyrovnal M. Bordoni, čo môže byt' inšpirujúce pre súčasnú teológiu v našom prostredí. Kedže ide o teológa, ktorý nie je až taký známy v našich zemepisných šírkach, v prvej časti sa stručne zoznámime s jeho osobnostou a teologickou tvorbou. Následne poukážeme na tažkosti, ktoré Bordoni vnímal pri aplikácii

1 Problematikou teologickej metódy v dogmatickej teológii sa zaoberá aj monografia: Ctirad V. Pospíšil. Hermeneutika mystéria. Struktury myšleni v dogmatické teologi. 2. vydanie. Praha: Kostelní Vydří: Krystal OP; Karmelitánské nakladatelství 2010. Zatial ide o jedinú monografiu publikovanú v Čechách, ktorá sa venuje tejto téme.

2 Porov. M. Bordoni. Dal Concilio Vaticano II al terzo millennio: il travaglio di un teologo. In: G. Ancona (ed.). Christus Omnium Redemptor. Cittá del Vaticano: Libreria Editrice Vaticana 2010, s. 13-14.

3 Obnova metódy v dogmatickej teológii siaha do 19. storočia, ked' sa začalo nové kritické skúmanie teologických prameňov. Porov. Pospíšil. Hermeneutika mystéria, s. 68. Následne mali na ňu vplyv rôzne teologické prúdy a školy, ktoré sa formovali v prvej polovici 20. storočia. Zvlášt' môžeme spomenút hnutie Nuovelle Théologie, ktoré sa rozvinulo vo Francúzsku a jeho niektorí predstavitelia sa neskôr stali protagonistami na II. vatikánskom koncile. Porov. R. Fisichella (ed.). Storia della teologia, 3. Da Vitus Pichler a Henri de Lubac. Bologna: EDB 1996, s. 443-471. 
geneticko-progresívnej metódy a predstavíme si metodologické východiská, ktoré sú podl'a nášho autora nevyhnutným predpokladom každého autentického teologického uvažovania. Hlavným východiskovým materiálom bude pre nás Bordoniho štúdia Dal Concilio Vaticano II al terzo millenio: il travaglio di un teologo (Od II. vatikánskeho koncilu k tretiemu tisícročiu: náročné úsilie jedného teológa), ktorú zanechal pri príležitosti ukončenia akademickej činnosti na Pápežskej lateránskej univerzite v r. 2000 a ktorá je akýmsi zhodnotením jeho 35 ročnej praxe teológa. Načrtáva v nej tažkosti, ktorým musel čelit́ v období po II. vatikánskom koncile, a taktiež sa v nej zaoberá otázkami teologickej metódy. Ide o štúdiu, ktorá predstavuje určité zavŕšenie jeho postojov v oblasti teologickej epistemológie.

\section{Marcello Bordoni - stručné údaje o jeho živote a tvorbe}

Marcello Bordoni sa narodil 27. januára 1930 v Ríme a zomrel 25. augusta 2013 v Genzane di Roma. Teologické štúdiá absolvoval na Pápežskej lateránskej univerzite (PLU). V roku 1954 bol vysvätený za kňaza pre Rímsku diecézu. Po obhájení dizertačnej práce na tému Il Tempo. Valore filosofico e spazio teologico v r. $1962^{4}$ začal pôsobit na PLU ako asistent pastorálnej teológie. V r. 1970 bol menovaný za mimoriadneho profesora na katedre kristológie a o tri roky neskôr za jej stáleho profesora. ${ }^{5}$ Svoju akademickú činnost' ukončil po dosiahnutí vekovej hranice v r. $2000 .{ }^{6}$ Počas svojho pôsobenia na PLU zastával rôzne pozície. V r. 1974-1977 bol dekanom Teologickej fakulty, v r. 1977-1981 jej prodekanom a v r. 1984-1987 riaditel'om Inštitútu pastorálnej teológie. Taktiež bol niekol'ko rokov šéfredaktorom teologického časopisu Lateranum. ${ }^{7}$

Činnost' M. Bordoniho sa nesústred'ovala len na univerzitné prostredie. Od r. 1992 pôsobil ako poradca Kongregácie pre náuku viery. Posledné roky jeho teologickej aktivity sa vztahovali na obnovenú Pápežskú teologickú akadémiu, kde bol v r. 1999 menovaný za jej

\footnotetext{
M. Bordoni. Il Tempo. Valore filosofico e spazio teologico. Roma: PUL 1965.

Porov. N. Ciola. Saggio introduttivo: Il percorso teologico-ecclesiale di Marcello Bordoni. In: M. Bordoni. Fare teologia nella Chiesa e due interviste teologiche. Città del Vaticano: Lateran University Press 2015, s. 8.

6 Porov. G. Ancona. Presentazione. In: M. Bordoni. Christus Omnium Redemptor, s. 9.

7 Porov. Ancona. Un profilo bio-bibliografico di Mons. Marcello Bordoni. In: I. Sanna (ed.). Gesù Cristo speranza del mondo. Miscellanea in onore di Marcello Bordoni. Roma: PUL-Mursia 2000, s. 11-12.
} 
prvého predsedu a v tejto pozícii ostal až do r. 2009. Toto prostredie mu pomohlo nadviazat kontakty s mnohými zahraničnými teológmi. Výsledkom ich vzájomnej spolupráce bolo oživenie časopisu $P A T H$ a knižnej edície nazvanej Itineraria. ${ }^{8}$

Marcello Bordoni bol mimoriadne plodným teológom. Jeho teologická tvorba sa vyznačuje špecifickým záujmom o kristológiu. Medzi jeho najvýznamnejšie diela patrí trilógia Gesú di Nazaret, Signore e Cristo,${ }^{9}$ jej skrátená verzia Gesú di Nazaret. Presenza, memoria, atte$s a,{ }^{10}$ monografia Cristologia nell'orizzonte dello Spirito, ${ }^{11}$ ako aj zbierka štúdií Christus omnium Redemptor. ${ }^{12}$ Teologická činnost' M. Bordoniho sa však nesústred'ovala len na kristologické tajomstvo. Venoval sa aj otázkam z oblasti eschatológie a zvlášt' v posledných rokoch svojej teologickej činnosti sa vrátil k témam teologickej epistemológie.

\section{Naliehavost́ obnovy v dogmatickej teológii}

Obnova teologickej metódy, ktorú so sebou priniesol II. vatikánsky koncil, predstavovala podstatnú zmenu v dogmatickej teológii. Nešlo len o otázku technického charakteru, ktorý dáva dôraz na vedeckost́ teológie, ale predovšetkým o spôsob uvažovania, ktoré je inšpirované zjavenou pravdou. ${ }^{13}$ Metóda je akoby dušou teológie, ktorá predurčuje jej tvárnost'. Jej obnova teda zahŕňa zmenu spôsobu myslenia a postojov. ${ }^{14}$

M. Bordoni nebol priamym účastníkom II. vatikánskeho koncilu, bol však jeho zanieteným pozorovatel'om. Obnova teologickej metódy,

8 Porov. Ancona. Presentazione, s. 9.

9 M. Bordoni. Gesù di Nazaret. Signore e Cristo. Saggio di cristologia sistematica, I. Problemi di metodo. Roma: Herder-Università Lateranense1982; Gesù di Nazaret. Signore e Cristo. Saggio di cristologia sistematica, II. Gesù al fondamento della cristologia. Roma: Herder-Università Lateranense 1982; Gesù di Nazaret. Signore e Cristo. Saggio di cristologia sistematica, III. Il Cristo annunciato dalla Chiesa. Roma: Herder-Università Lateranense 1986. V súčasnosti s odstupom 30 rokov vychádza nové vydanie Bordoniho trilógie. Zatial' boli publikované prvé dva diely: M. Bordoni. Gesù di Nazaret. Signore e Cristo. Saggio di cristologia sistematica, I. Problemi di metodo. N. Ciola, A. Sabetta, P. Sguazzardo (eds.). Bologna: EDB 2016; Gesù di Nazaret Signore e Cristo. Saggio di cristologia sistematica. 2. Gesù al fondamento della cristologia. N. Ciola, A. Sabetta, P. Sguazzardo (eds.). Bologna: EDB 2017.

10 M. Bordoni. Gesù di Nazaret. Presenza, memoria, attesa. Brescia: Queriniana 1988.

11 M. Bordoni. La cristologia nell'orizzonte dello Spirito. Brescia: Queriniana 1995.

12 M. Bordoni. Christus omnium Redemptor. Città del Vaticano: Libreria Editrice Vaticana 2010.

13 Porov. M. Bordoni. Editoriale. PATH 3 (2004), s. 3.

14 Porov. Pospíšil. Hermeneutika mystéria, s. 72. 
ktorú presadzoval koncil, v ňom ako v mladom začínajúcom teológovi vzbudzovala vel'ký záujem. Už počas svojich štúdií si uvedomoval slabé stránky dogmatickej metódy, ktorej chýbala zrelá reflexia ohl'adom otázky historickosti. Dogmatická metóda vychádzala z definícií Učitel'ského úradu Cirkvi, ${ }^{15}$ následne hl'adala potvrdenie učenia v jednotlivých citáciách Písma a v tradícii a až nakoniec sa pokúšala prehíbit́ poznanie viery. ${ }^{16}$ Teológia tak strácala svoju autonómiu a riskovala, že sa stane len akousi predíženou rukou Magistéria a obmedzí sa iba na zhromažd'ovanie dôkazov, ktoré už Magistérium potvrdilo. ${ }^{17}$

Obnova teologickej metódy, tak ako je načrtnutá v koncilovom dokumente Optatam totius 16 , predstavuje radikálnu zmenu. Východiskovým bodom tzv. „geneticko-progresívnej metódy“ nie je dogmatická definícia alebo téza, ale Písmo ako celok, teda teológia obsiahnutá v Božom slove a nielen jednotlivé citácie vytrhnuté z kontextu. Následne je potrebné venovat pozornost́ jednotlivým etapám rozvoja právd viery, prechádzat pritom učením cirkevných otcov, ako aj dejinami dogiem. Je dôležité, aby teológia hl'adala riešenie na l'udské problémy vo svetle Božieho zjavenia, aplikovala večné pravdy na meniace sa podmienky tohto sveta a komunikovala ich vhodným spôsobom súčasným l'ud'om. ${ }^{18}$

Bordoni si uvedomoval, že II. vatikánsky koncil urobil významný posun ohl'adom teologickej metódy. Nová metóda zdôraznila dôležitost' štúdia Písma, ktoré má jasné prvenstvo v teológii a je akoby „dušou celej teológie“. ${ }^{19}$ Tento silný dôraz na Písmo a tradíciu viedol k oživeniu teológie a zvlášt kristológie. Na druhej strane sa však postupne vynárali tažkosti spojené s aplikáciou obnovenej metódy. ${ }^{20}$

Bordoni hovorí o určitých neistotách geneticko-progresívnej metódy, ktoré sa prejavili hned' po koncile, ale aj neskôr. Priznáva, že ako systematický teológ mal tažkost' nájst' jednotiace kritérium, vlastné teologicko-systematickému uvažovaniu. Týmto kritériom nemohla byt' len

15 Pri písaní vel'kých písmen v náboženskej terminológii rešpektujem pravidlá vydané Združením katolíckych vydavatel'stiev Slovenska (ZKVS) v Trnave 31. 3. 2006.

16 Porov. Bordoni. Dal Concilio Vaticano II, s. 17; Pospíšil. Hermeneutika mystéria, s. 60-62.

17 Porov. J. Ratzinger. Úvod k instrukci Kongregace pro nauku víry Donum Veritatis, o cirkevním povolání teologa. (24. máj 1990), český preklad. Olomouc 1999, s. 5.

18 Porov. Bordoni. Dal Concilio Vaticano II, s. 18; Pospíšil. Hermeneutika mystéria, s. $68-72$.

19 Porov. $O T$, čl. 16; $D V$, čl. 24.

20 Porov. Bordoni. Dal Concilio Vaticano II, s. 19. 
akási mechanická následnost' faktov vychádzajúcich z Písma, učenia cirkevných otcov, koncilov a Magistéria, po špekulatívne spracovanie a preloženie jazyka viery do súčasnej kultúry. Jednotlivé kroky novej metodológie nevytvárali systematickú súdržnost́. Bordoni poukázal hlavne na dve výzvy, ktorým musel čelit. Prvá sa týkala biblického prístupu a druhá hermeneutického poslania teológie. ${ }^{21}$

Vzhl'adom na biblický prístup Bordoni priznal, že pre systematického teológa išlo o náročnú výzvu. Cítil sa, akoby sa mal zrieknut vlastných kompetencií a vstúpit na pole exegézy, kde sa cítil neistý. Často sa stávalo, že odborníci na systematickú teológiu sa dostávali do konfliktu s exegétmi, ktorí si nárokovali určité prvenstvo a prevahu vzhladom na teologickú metódu. To viedlo k tomu, že mnohí systematickí teológovia začali postupovat́ ako biblisti, bez toho, aby boli odborníkmi v danej oblasti, a biblisti si nárokovali určitú prevahu na poli teologických štúdií, pričom často nepoznali učenie tradície Cirkvi. ${ }^{22}$

Podobný problém existoval aj pri prechádzaní cez patristickú teológiu, učenie koncilov, stredovekú teológiu až k momentu, ktorý koncil vyjadril nasledovne: „(študenti) nech sa učia hladat' riešenie l'udských problémov vo svetle Božieho zjavenia, aplikovat́ zjavené večné pravdy na menlivé podmienky tohto sveta a prístupným spôsobom ich podávat' súčasným l'ud'om“. ${ }^{23} \mathrm{~V}$ tejto súvislosti sa náš autor pýta, či toto hermeneutické poslanie teológie je len finálnym momentom, tak ako to naznačuje samotný dokument. Nemal by si systematický teológ už na začiatku bádania položit' otázky ohl'adom života a kultúry, z ktorej vychádza, a s týmto poznaním pristupovat k Písmu, učeniu cirkevných otcov, koncilov a Magistéria? Bordoni si uvedomoval jednostrannost́ dokumentu Optatam totius, ktorý dal dôraz na deduktívny moment vychádzajúci zo zjavenia smerom k životu. ${ }^{24}$ Zároveň podčiarkol skutočnost', že systematický teológ musí poznat potreby súčasnej kultúry a tak prechádzat́ celou tradíciou viery, a zamerat́ sa pritom na odovzdávanie zjavenej pravdy v priebehu dejín, aby ju urobil stále živou a aktuálnou pre ohlasovanie evanjelia l'ud'om dnešnej doby. ${ }^{25}$ Podl'a Bordoniho nevyhnutným poslaním systematickej teológie je:

21 Porov. Bordoni. Dal Concilio Vaticano II, s. 19.

22 Porov. Bordoni. Dal Concilio Vaticano II, s. 20.

23 OT, čl. 16.

${ }^{24}$ Na tento problém poukázal aj C. V. Pospíšil. Porov. Pospíšil. Hermeneutika mystéria, s. 71 .

25 Porov. Bordoni. Dal Concilio Vaticano II, s. 20-21. 
otvorit cesty k pochopeniu zjavenej pravdy v jej stálej hodnote a zároveň sledovat dialóg viery s kultúrami, ktorý je vedený Duchom, poukazovat́ na to, ako zjavená pravda v Ježišovi Kristovi, v srdci trojičného tajomstva, vytvára svetlo, ktoré objasňuje existenciu každého človeka v každej dobe a za akýchkolvek podmienok a vytvára základ aj pre dialóg s ostatnými náboženskými skúsenostami. ${ }^{26}$

Inými slovami môžeme povedat, že Bordoni kladie dôraz na požiadavku relektúry, ktorá ponúka systematickému teológovi nové zorné uhly poznania, umožňujúce mu objavovat' bohatstvo tajomstva zjavenej pravdy a odkrývat' ho pre človeka danej doby a daného miesta. ${ }^{27}$

\section{Teologická metóda ako predmet Bordoniho reflexie}

Aplikácia novej teologickej metódy priniesla so sebou sériu metodologických otázok, s ktorými sa bolo potrebné vyrovnat. Ako na tieto problémy reagoval Bordoni? Vo svojej reflexii Dal Concilio Vaticano II al terzo millennio načrtáva niekol'ko základných metodologických predpokladov, ktoré sú nevyhnutné pre každé teologické uvažovanie. ${ }^{28}$ $\mathrm{V}$ prvom rade ide o metafyzické predpoklady teologickej reflexie, následne objasňuje vztah medzi Písmom a Tradíciou a nakoniec poukazuje na základné princípy teologickej metódy. Skôr ako pristúpime k analýze týchto požiadaviek, upriamime pozornost' na pramene, ktoré ovplyvnili Bordoniho myslenie ohladom teologickej metódy.

\subsection{Pramene Bordoniho reflexie}

Hned' na úvod môžeme konštatovat, že samotný článok nám neprezrádza, ktorí autori najviac ovplyvnili Bordoniho myslenie ohladom teologickej metódy. Táto skutočnost' je pochopitelná, pretože daná štúdia predstavuje akési zavŕšenie jeho postojov. Sám autor sa v nej opiera predovšetkým o svoju dlhoročnú skúsenost' a odvoláva sa na vlastné články, ktoré predchádzali tejto reflexii. Pohl'ad do nich nám prezrádza viac.

Z Bordoniho tvorby sa dozvedáme, že otázkam teologickej metódy sa venoval už počas svojej teologickej formácie. V tomto období ho

26 Bordoni. Dal Concilio Vaticano II, s. 21-22.

27 Porov. Pospíšil. Hermeneutika mystéria, s. 71.

28 Porov. Bordoni. Dal Concilio Vaticano II, s. 22. 
vel'mi zaujali práce O. Cullmanna a J. Mourouxa. ${ }^{29}$ Podporovaný prostredím, ktoré bolo otvorené novým perspektívam $\mathrm{v}$ teológii, $\mathrm{v}$ ňom narastal silný záujem o štúdium témy „časnosti“ a „hodnoty historickosti“, o čom svedčí aj téma jeho doktorskej práce - Il tempo. Valore filosofico e mistero teologico. ${ }^{30}$ Bordoni následne viackrát priznal, že klúčovú úlohu počas jeho teologickej formácie zohrávala skúsenost́ z pastoračného prostredia. Práve tu si naplno uvedomoval nedostatočnost' teologického prístupu v základných dogmatických traktátoch a zároveň aj existenciu akéhosi rozkolu medzi učením, životnou skúsenostou a teologickým ohlasovaním. Táto skúsenost' ho podnietila k sledovaniu nových kerygmatickejšich pokusov v teológii. Zaujímal sa o traktáty M. Schmausa, ktorý viackrát podčiarkol, že teológia musí byt' teológiou ohlasovania, v opačnom prípade nejde ani o teológiu, ani o vedu. Všímal si niektoré kroky hnutia Nuovelle Théologie, najmä čo sa týkalo výzvy „návratu k prameňom“, ale tiež si uvedomoval aj jeho určité medzery ohl'adom epistemologických otázok. Vel'kú oporu nachádzal u svojho učitel'a dogmatiky P. Parenteho, ktorý ho povzbudzoval, aby vypracoval „živú teológiu“. ${ }^{31}$

Počas svojej teologickej tvorby sa viackrát zaoberal otázkami teologickej epistemológie, zvlášt v posledných rokoch svojej činnosti. ${ }^{32}$ Vo svojich štúdiách sa predovšetkým opiera o dokumenty II. vatikánskeho koncilu a Magistéria. Medzi najčastejšie citovaných autorov patria W. Kasper a J. Ratzinger - Benedikt XVI. Na viacerých miestach sa odvoláva na ich rôzne štúdie z oblasti teologickej epistemológie. K d'alším často citovaným autorom patria Z. Alszeghy, M. Flick,

29 Ide o nasledovné diela: O. Cullmann. Christ et le temps. Neuchàtel - Paris: Delachaux \& Niestlé 1966; J. Mouroux. Le mystère du temps. Approche theologique. Paris: Aubier 1962.

30 M. Bordoni. Il Tempo. Valore filosofico e mistero teologico. Roma: PUL 1965.

31 Porov. Bordoni. Dal Concilio Vaticano II, s. 15-16.

32 K Bordoniho najvýznamnejším článkom z oblasti teologickej epistemológie patria: La teologia sistematica tra ortodossia e ortoprassi. Lateranum, 54 (1988), s. 266-287; La croce nella struttura epistemologica del sapere teologico. La sapienza della croce, 4 (1989), s. 13-29 (neskôr upravený a publikovaný v M. Bordoni. Fare teologia nella Chiesa e due interviste teologiche. Roma: Lateran University Press 2015, s. 29-56); Riflessioni introduttive: il travaglio della teologia alla ricerca di nuove forme del sapere. In: I. Sanna (ed.). Il sapere teologico e il suo metodo. Teologia ermeneutica e verità. Bologna: EDB 1993, s. 11-40. Následne ide o príspevky publikované v teologickom periodiku $P A T H$, zvlášt jeho editoriál k číslam PATH 3 (2004), PATH 1 a 5 (2006), ktoré boli celé venované téme teologickej metódy, ako aj o jeho štúdiu La Tradizione vivente della Parola e l'azione molteplice dello Spirito. PATH, 5 (2006), 73-85. 
H. U. von Balthasar, M. Seckler, biblista R. Penna či filozof P. Gilbert, ale aj predstavitelia scholastickej teológie Bonaventúra a Tomáš Akvinský.

\subsection{Metafyzické predpoklady teologického uvažovania}

Tému metafyzických predpokladov teologického uvažovania Bordoni rozvinul na základe otázok, ktoré sa vynorili v teologickej diskusii po II. vatikánskom koncile. Táto problematika mu zvlášt́ ležala na srdci. ${ }^{33}$ Základný problém podl'a neho spočíva v prepojení teologického uvažovania o zjavenej pravde s historickým rozmerom l'udského myslenia, ktoré má schopnost́ poznávat' ontologickú pravdu. ${ }^{34}$ Inými slovami, je potrebné nájst' možnosti prepojenia medzi historickostou l'udského myslenia a metafyzickým princípom ontologického základu pravdy a zároveň medzi ontologickým základom pravdy a poznaním viery, ktoré vychádza z Božieho zjavenia. Bordoni zároveň konštatoval, že teológia, ktorá sa neopiera o princípy metafyziky, nevyhnutne hl'adá svoju oporu pre pochopenie viery bud' vo filozofii jazyka, alebo v humánnych vedách, akými sú sociológia či psychológia. Pohybuje sa tak po krehkom teréne, bez pevných základov. ${ }^{35}$

Rímsky teológ zároveň upozornil, že teológia v snahe prekonat prehnanú analytickú štruktúru myslenia, typickú pre vrcholnú neoscholastickú teológiu, sa pokúšala vyhnút metafyzickým princípom. Tým však strácala prístup k absolútnej pravde a prevládalo v nej historizujúce myslenie. Môžeme sa pýtat', či v danom prípade je ešte možné hovorit́ o teológii v pravom slova zmysle. ${ }^{36}$ Podla Bordoniho išlo o ignorovanie dôležitého epistemologického problému - stretnutia pravdy s dejinami, čo l'ahko viedlo k upadnutiu do dvoch opačných extrémov: bud' do čisto metafyzického poznania, alebo do historicko-relativistického chápania skutočnosti. V tejto súvislosti náš autor prezentoval dôležitú požiadavku: objasnit' štruktúru teologického uvažovania, a to vzhladom na základnú funkciu l'udského myslenia, ktoré je otvorené metafyzickej pravde, ako aj vzhl'adom na kristologickú udalost', ktorá je eschatologickým miestom zjavenej pravdy, uskutočnenej v dejinách

\footnotetext{
Tejto téme sa M. Bordoni venoval aj v článku Riflessioni introduttive: il travaglio della teologia alla ricerca di nuove forme del sapere. In: I. Sanna (ed.). Il sapere teologico e il suo metodo. Teologia ermeneutica e verità. Bologna: EDB 1993, s. 11-40.

34 Danou problematikou sa v širšom rozmere zaoberá encyklika Jána Pavla II. Fides et ratio (vyhlásená 14. septembra 1998), slovenský preklad: Bratislava 1998.

35 Porov. Bordoni. Dal Concilio Vaticano II, s. 23.

36 Porov. Bordoni. Dal Concilio Vaticano II, s. 23; Bordoni. Riflessioni introduttive, s. 20.
} 
a zavŕšenej na kríži a v zmŕtvychvstaní. Bordoni je presvedčený, že teologické uvažovanie nachádza svoj model práve v stretnutí medzi pravdou a dejinami v udalosti Krista. Teológia by mala reflektovat a vyjadrit chápanie človeka sledujúc vnútornú logiku viery. Viera, ktorá vychádza zo svetla v dejinách zjavenej pravdy, nikdy nemôže ignorovat pravdu rozumu, ktorá sprevádza vieru, pretože je vyjadrením l'udskej činnosti. Úlohou teológie teda je intellectus fidei - chápanie viery, ktoré otvára nové horizonty pravdy, ako aj veriace uvažovanie, ktoré je historicky vyjadrené a zasadené do foriem l'udského myslenia. ${ }^{37}$

Pre teológiu z uvedeného vyplýva, že nemôže existovat' bez určitého metafyzického predporozumenia. Aj ked' metafyzika nie je prameňom teológie, je akoby nevyhnutnou atmosférou pre dýchanie, zdôraznil Bordoni. Na druhej strane teológia nemôže ignorovat' skutočnost', že ludské myslenie je historicky podmienené. Zjavenú pravdu spoznávame v dejinách. ${ }^{38}$

Bordoni potvrdil, že prijatie gnozeologického princípu historickosti je zlučitel'né s otázkou pravdy. Tým vyjadril dôveru v l'udské uvažovanie pri hl'adaní pravdy. Sám podotkol, že jednou z primárnych úloh teológie je:

vrátit človeku „dôveru“ a „odvahu“ uvažovat' v dobrodružstve hladania pravdy. Bez tohto základného predpokladu Božie slovo, ktoré je „vždy božským slovom v ludskej reči, by nebolo schopné povedat o Bohu celkom nič“ (FR 84). ${ }^{39}$

Pre teológiu z toho vyplýva, že hoci má svoj východiskový bod v Božom slove, nevyhnutne sa musí vo svojom bádaní stretnút aj s l'udským hl'adaním pravdy, a to v dialógu s filozofiou, ktorá má metafyzický dosah. V tejto súvislosti Bordoni hovorí o neustálom „kruhovom dynamizme“ pri hl'adaní pravdy. ${ }^{40}$ Odvoláva sa pri tom na slová, vtedy ešte kardinála J. Ratzingera:

Načúvanie Slovu, ktoré sa stalo dejinami a hladanie rozumu sa neustále stretávajú. Týmto spôsobom na jednej strane sa viera prehlbuje a očistuje

37 Porov. Bordoni. Dal Concilio Vaticano II, s. 23-24.

38 Porov. Bordoni. Dal Concilio Vaticano II, s. 24-25; Bordoni. Riflessioni introduttive, s. 18.

39 Bordoni. Dal Concilio Vaticano II, s. 26.

40 Porov. Bordoni. Dal Concilio Vaticano II, s. 26. 
a na druhej strane aj myslenie sa obohacuje, pretože sa mu otvárajú nové horizonty. ${ }^{41}$

Bordoni objasnil, že toto je možné, pretože tajomná tvár pravdy, ktorú človek hl'adá, nie je abstraktnou pravdou, ale osobným Absolútnom, ktoré pritłahuje človeka tým, že mu vychádza v ústrety. Pravda, ktorá sa dáva v dejinách, vytvára medziosobný vztah a ukazuje nám cestu smerom k nej. Pozýva l'udskú slobodu do hry a dáva jej schopnost' odpovedat' sebadarovaním sa Pravde. ${ }^{42}$

\subsection{Sväté písmo a výklad Božieho zjavenia v tradícii}

Druhý základný problém, ktorý sa objavil v systematickej teológii v pokoncilovom období, sa vztahuje na integráciu dokumentu Optatam totius s hlavnými konštitúciami Dei verbum, Lumen gentium a Gaudium et spes. Vzhl'adom na danú problematiku Bordoni podčiarkol niekol'ko dôležitých aspektov. ${ }^{43}$

Najskôr bolo potrebné objasnit pojem prameň teológie a zároveň aj vztah medzi Písmom a Tradiciou.$^{44} \mathrm{~V}$ súvislosti s touto problematikou Bordoni upozorňuje na dôležité konštatovanie kardinála A. Vanhoyea, ktorý v jednej zo svojich štúdií ${ }^{45}$ poukázal na reštriktívne interpretovanie učenia dogmatickej konštitúcie Dei verbum, čo poškodilo recepcii samotného dokumentu. Mnohí autori sa totiž mylne domnievali, že „jediným prameňom“ teológie, o ktorom hovorí dokument, je Písmo. Bolo teda potrebné objasnit, že predmetom dokumentu Dei verbum nie je len Písmo, ale celé Božie zjavenie. Inými slovami: prioritným prameňom viery a teológie je Božie Slovo vtelené v udalosti Krista. ${ }^{46}$ Tento

41 J. Ratzinger. Per una lettura dell'enciclica Fides et Ratio. Città del Vaticano: Libreria Editrice Vaticana 1999, s. 248.

42 Porov. Bordoni. Dal Concilio Vaticano II, s. 28; Ján Pavol II. Fides et ratio, čl. 32.

43 Porov. Bordoni. Dal Concilio Vaticano II, s. 29.

44 Výrazy „Tradícia“ s velkým začiatočným písmenom a „tradícia“ s malým začiatočným písmenom majú v teológii rozdielnu hodnotu. Pojem „Tradícia“ sa vztahuje na apoštolskú Tradíciu, ktorá je nositel'kou zjavenej pravdy. Pojem „tradícia“ sa vztahuje na rôzne ekleziálne tradície. Pri písaní nie je vždy lahké rozlíšit či ide o „Tradíciu“, alebo „tradície“. Z tohto dôvodu budeme používat výraz „Tradícia“ s vel'kým písmenom len ked' bude zjavné, že ide o apoštolskú Tradíciu. V ostatných prípadoch budeme uvádzat pojem „tradícia“ s malým písmenom. Rešpektujeme tak odporúčanie dokumentu MTK Teologie dnes, čl. 31, v českom preklade poznámka pod čiarou č. 76. Ide o článok: A. Vanhoye. La parola di Dio nella vita della Chiesa. La recezione della Dei Verbum. In: R. Fisichella (ed.). Il Concilio Vaticano II. Ricezione ed attualità alla luce del Giubileo. Cinisello Balsamo: San Paolo 2000, s. 29-45.

46 Porov. Bordoni. Dal Concilio Vaticano II, s. 29-30. 
„jediný prameň pravdy“, o ktorom hovorí Dei verbum 7, sa nám ponúka prostredníctvom dvoch ciest - posvätnej Tradicie a Svätého písma.

Ako chápat' vztah medzi Písmom a Tradíciou? Bordoni upozorňuje, že ho nemôžeme chápat' kvantitatívnym spôsobom, ale kvalitativne, kruhovo, hermeneuticky. Ide teda o vzájomné prestupovanie medzi Písmom a Tradíciou. Ak sa chceme priblížit k Božiemu zjaveniu, musíme vychádzat' z Písma, pretože ono je privilegovaným miestom tradície, z ktorej vychádza, aj ked' ju neobsahuje integrálnym spôsobom. Toto privilégium spočíva v tom, že ide o inšpirovaný text Duchom Svätým a že sa viaže na obdobie zakladajúcej udalosti viery. Na druhej strane ak však Písmo nie je oživované živou tradíciou, je len mŕtvou literou, ktorá zabíja (2 Kor 3,6). ${ }^{47}$ Je to práve úloha tradície podávat' Božie slovo integrálnym spôsobom. ${ }^{48}$

V Bordoniho texte je zjavné, že ked' hovorí o Tradícii, nerozlišuje medzi „apoštolskou Tradíciou“ a „inými tradíciami“. Tento fakt môžeme chápat' aj ako určitú medzeru, pretože pojem „tradícia“ nie je jednoznačný. II. vatikánsky koncil síce túto rozdielnost́ naznačil, ale hlbšie ju nerozpracoval. ${ }^{49}$ Až v dokumente Medzinárodnej teologickej komisie (MTK) Teologie dnes z r. 2012 nachádzame jasné rozlíšenie medzi apoštolskou Tradíciou a inými - tzv. ekleziálnymi - tradíciami, ktoré spadajú do jednotlivých časových období v dejinách Cirkvi. ${ }^{50}$

Apoštolská Tradícia predstavuje živý proces odovzdávania viery. ${ }^{51}$ Jej obsahom nie je iba učenie, ale nadprirodzený život $\mathrm{z}$ viery v ekleziálnom spoločenstve. Je akoby „prúdom nadprirodzeného života“, ktorý sa šíri v dejinách prostredníctvom ohlasovaného Božieho slova, sviatostí, svedectva života. ${ }^{52}$ Apoštolská Tradícia však nie je niečím abstraktným. Existuje konkrétne v rôznych tradíciách, ktoré sa vytvárali vo vnútri Cirkvi. ${ }^{53}$ Tieto sú akoby „výrazovým prostriedkom, ktorý viac či menej odráža apoštolskú Tradíciu“. ${ }^{44}$ Rozlišovanie apoštolskej Tradície od jej kultúrne a historicky podmienených výrazových foriem

\footnotetext{
Porov. Bordoni. Dal Concilio Vaticano II, s. 30.

Porov. $D V$, čl. 9 .

Porov. Pospíšil. Hermeneutika mystéria, s. 75.

Porov. MTK. Teologie dnes, čl. 31; C. V. Pospíšil. Inspirace a otazníky obsažené v dokumentu MTK. Teologie dnes. In: Studia theologica 1/ 2013, s. 84-86.

Porov. $D V$, čl. 8.

52 Porov. C. V. Pospíšil. Vybrané inspirace obsažené v prvních třech kapitolách Dei verbum. AUC Theologica 2/2012, s. 27.

53 Porov. MTK. Teologie dnes, čl. 31.

54 Pospíšil. Inspirace a otazníky, s. 86.
} 
nám umožňuje rozpoznávat', čo je v Cirkvi trvalé a stále od jej premenlivého života. ${ }^{55}$ Zatial čo apoštolskú Tradíciu nemôžeme podrobovat́ kritike, ekleziálne tradície musia byt' otvorené posudzovaniu, aby sa Cirkev mohla neustále obnovovat. ${ }^{56}$

\subsection{Základné princípy teologickej metódy}

Vrát'me sa k Bordonimu a spolu s ním si položme otázku: Aký postoj by mal zaujat́ systematický teológ k Písmu ako k základnému prameňu teológie? Bordoni viackrát podčiarkol, že systematický teológ by nemal pristupovat k biblickým textom len čisto exegetickým spôsobom, zameraným na pochopenie samotného textu a úmyslu autora, ako je to v prípade odborníkov na exegézu. Jeho prístup musí byt' lektúrou viery, ktorá mu umožňuje objavovat' v Písme významy, ktoré by mu ináč unikli. ${ }^{57}$

V tejto súvislosti je potrebné poznamenat, že Písmo nie je len l'udským slovom, ale predovšetkým Božím slovom v ludskej reči. Ide o inšpirované l'udské slovo, ktoré odkazuje nad seba. Preto mu čitatel' môže porozumiet' len vtedy, ak je „v živom spojení s Tým, ktorý prostredníctvom tohto slova vypovedá o sebe a chce sa nám darovat"“. ${ }^{58}$ Týmto spôsobom môžeme chápat' to, čo Bordoni nazýva „lektúrou viery“. Ide o základné pravidlo hermeneutiky mystéria, ${ }^{59} \mathrm{z}$ ktorého pre teologickú metódu vyplývajú d'alšie tri dôležité princípy, na ktoré poukázal náš autor. ${ }^{60}$

Na prvom mieste Bordoni hovorí o tzv. kristologickom princípe. Ide o podstatný hermeneutický princíp, ktorý vyjadruje, že udalost́ Krista tvorí základ jednoty a celistvosti Písma. Je „stredobodom, ku ktorému smerujú všetky Písma počnúc Starým zákonom, ako súbor kanonických kníh““. ${ }^{61}$ Na základe tohto princípu „nie je možné uprednostňovat’ jednotlivú knihu alebo tvrdenie bez zasadenia do celkového kontextu samotného Písma a Cirkvi“. ${ }^{62}$ Bordoni sa pritom odvoláva na dokument Pápežskej biblickej komisie (PBK) Interpretácia Biblie v Cirkvi, ktorý

\footnotetext{
Porov. Pospíšil. Vybrané inspirace, s. 27.

Porov. MTK. Teologie dnes, čl. 31.

Porov. Bordoni. Dal Concilio Vaticano II, s. 31.

Pospíšil. Hermeneutika mystéria, s. 83.

Porov. Pospíšil. Hermeneutika mystéria, s. 83.

Porov. Bordoni. Dal Concilio Vaticano II, s. 31.

Bordoni. Dal Concilio Vaticano II, s. 32.

Bordoni. Dal Concilio Vaticano II, s. 32.
} 
zdôrazňuje, že Biblia nie je zbierkou textov bez vzájomných vztahov, ale predstavuje ,jednotný celok svedectiev tej istej vel'kej tradície““. ${ }^{63}$

S týmto súvisí aj dôležitost' „kánonického prístupu“ k Písmu, o ktorom hovorí dokument. Ten uprednostňuje „takú teologickú metódu interpretácie, ktorá sa [...] opiera sa o Bibliu ako celok“. ${ }^{64}$ Úlohou systematického teológa je teda interpretovat' biblický text „vo svetle kánona Svätého písma, ktoré je normou viery určitého spoločenstva veriacich“. ${ }^{65}$ Kánonický prístup, ktorý je založený na kristologickom princípe, tak reaguje proti prílišnému preceňovaniu toho, čo sa v Písme považuje za originálne a pôvodné, akoby iba to mohlo byt' autentické ${ }^{6}$ Podla Bordoniho kristologický princíp môžeme vnímat' ako „dynamický pól“, ktorý spája Starý a Nový zákon, ako to vyjadruje aj známy výrok sv. Augustína: „Novum Testamentum in Vetero latet et in Novo, vetus patet". ${ }^{67}$ Inými slovami: knihy Starého zákona nadobúdajú ich plný význam, ked' sú čítané vo svetle Nového zákona, a naopak, knihy Nového zákona sú chápané lepšie vzhl'adom na Starý zákon. Bordoni tak podčiarkol, že princíp jednoty Písma je usmerňovaný základným kristologickým princípom, ${ }^{68}$ pretože v Kristovi sa uskutočňuje definitívne zjavenie Boha. „On nielen komunikuje Slovo pravdy, ale je týmto Slovom.“69 V ňom sa nám zjavuje, že Písmo nie je len informáciou o Bohu, ale sebadarovaním sa Trojjediného. ${ }^{70}$

Druhý dôležitý princíp, na ktorý poukázal náš autor, je pneumatologický. Ide o princíp, ktorý je obsiahnutý v tvrdení Dei verbum 12: „Sväté písmo sa má čítat a vysvetlovat' v tom istom Duchu, v ktorom bolo napísané.“ To znamená, že ak je Písmo dielom Ducha, musíme ho čítat' skrze Ducha a v Duchu, len tak môžeme odkryt', čo nám Boh chce povedat' daným textom. ${ }^{71}$ To ale neznamená, že ide o čisto spiritu-

${ }^{63}$ PBK. Interpretácia Biblie v Církvi. Slovenský preklad: Spišská Kapitula - Spišské Podhradie: Kňazský seminár biskupa J. Vojtašáka 1995, s. 53.

${ }_{64}$ PBK. Interpretácia Biblie, s. 53.

65 PBK. Interpretácia Biblie, s. 53.

66 Porov. PBK. Interpretácia Biblie, s. 54.

67 S. Agostino. Quest. in Hept 2, 73. In: PL 34, 623. Podla Bordoni. Dal Concilio Vaticano II, s. 32 .

68 Porov. Bordoni. Dal Concilio Vaticano II, s. 32-33.

69 M. Bordoni. Cristo centro della Scrittura e pienezza della Rivelazione. In: M. Tábet (ed.). La Sacra Scrittura anima della Teologia. Atti del IV Simposio Internazionale della Facoltá di Teologia della Pontificia Universitá della Santa Croce. Cittá del Vaticano: Libreria Editrice Vaticana 1999, s. 125.

70 Porov. Pospíšil. Hermeneutika mystéria, s. 82.

71 Porov. $D V$, čl. 12; Verbum Domini, čl. 16. 
álne chápanie Písma, ktoré by ignorovalo historicko-kritický prístup. Podstatné je, aby systematický teológ pristupoval k biblickému textu ako veriaci človek.

Pneumatologický princíp (...) pozýva systematického teológa pristupovat́ k Písmu v jeho objektívnosti a jednote, ale vždy musí pamätat na to, že je „ovocím tradície“. A preto, že je oživované tým istým Duchom, ktorý ho inšpiroval, princíp živej tradície zahŕňa aj to poznanie pravdy, ktorá presahuje samotný pisaný text a odkazuje na plnost́ obsahu, ktorý sa nachádza integrálnym spôsobom $v$ živej tradicii Cirkvi. ${ }^{72}$

Z uvedeného následne vyplývajú dva konkrétne dôsledky, ktoré Bordoni podčiarkol. V prvom rade systematický teológ nikdy nemôže vychádzat' len z Písma a zabúdat' na to, že je súčastou živej tradície Cirkvi. Podobne by nemal pristupovat ani k post-biblickej tradícii a vnímat' ju ako nejaký druhý moment, bez dostatočného dôrazu na Písmo, ktoré je dušou celej teológie. Systematický teológ teda nemôže postupovat' len čisto deduktívne: vychádzat' z Písma a postupne prechádzat' celou tradíciou smerom k životu a vnímat́ pritom jednotlivé časové obdobia oddelene. Podla Bordoniho ide o nesprávny spôsob interpretácie geneticko-progresívnej metódy. ${ }^{75}$ Systematický teológ musí postupovat' aj induktívne. ${ }^{74}$ Musí vychádzat' zo života a kultúry, v ktorej žije, a pristupovat' k Písmu ako k dokumentu viery, teda ako k inšpirovanému textu Duchom Svätým. Podobne má pristupovat' i k tradícii, v ktorej tiež pôsobí Duch, ktorý mu „umožňuje pochopit’ aj tie významové horizonty, ktoré vypíňajú vzdialenost' medzi písaným textom a živým porozumením Cirkvi“ ${ }^{75}$ Pretože Božie zjavenie je dialogickou udalostou, ktorá oslovuje l'udí každej doby a každého miesta. ${ }^{76}$

Druhým dôsledkom vyplývajúcim z pneumatologického princípu je nevyhnutnost' prekonat́ akýkol'vek dualizmus medzi vedeckým prístupom k Písmu a lektúrou viery. Nejde o dva rozdielne prístupy, ale o dva aspekty jedného teologického uvažovania, ktoré nie je možné

\footnotetext{
Bordoni. Dal Concilio Vaticano II, s. 34.

Porov. Bordoni. Dal Concilio Vaticano II, s. 35.

74 Porov. Bordoni. La Tradizione vivente della Parola e l'azione molteplice dello Spirito. PATH 5 (2006), s. 78.

75 Bordoni. Dal Concilio Vaticano II, s. 35.

76 Porov. Pospíšil. Inspirace a otazníky, s. 77. Autor článku poznamenáva, že celá prvá kapitola dokumentu MTK Teologie dnes hovorí o načúvaní Svätému písmu, čo predpokladá, že Božie zjavenie je dialogickou udalostou.
} 
od seba oddelit'. Vedecký prístup k Písmu je nevyhnutným predpokladom lektúry viery. Ale práve špecifický uhol pohladu viery umožňuje systematickému teológovi objavovat prostredníctvom textu Písma významy, ktoré presahujú písaný text a nie sú s ním v kontraste. ${ }^{77}$ Pretože, ako podčiarkol Bordoni: „viera nevytvára významy, ale vytvára svetlo (pochádzajúce $z$ Ducha), vd'aka ktorému môže čitatel' pochopit' významy, ktoré nie sú v texte vyjadrené, ale sú v ňom obsiahnuté a ktoré by bez jej svetla unikli čitatel'ovi““. ${ }^{78}$ Poznanie úmyslu svätopisca je teda na jednej strane nevyhnutným prostriedkom, ktorý nám umožňuje spoznávat' zmýšlanie Boha. Na druhej strane však Božie zjavenie presahuje svedectvo jednotlivého svätopisca. Preto je potrebné, aby Sväté písmo bolo čítané a vysvetlované $\mathrm{v}$ tom istom Duchu, ktorým bolo inšpirované. ${ }^{79}$

Tretím princípom, ktorý náš autor zdôraznil, je ekleziologický princíp. Bordoni vo svojom uvažovaní vychádza z tažkosti, ktorej príčinou je určité nepochopenie vztahu medzi poznaním viery a ekleziálnym spoločenstvom. V tejto súvislosti podčiarkol, že Cirkev ako ekleziálne spoločenstvo nie je len locus theologicus - čiže prostredie, v ktorom sa uskutočňuje teologické bádanie, ale je zároveň aj aktívnym subjektom teológie. Jednotliví teológovia či skupina teológov nemôžu uskutočňovat vedeckú teológiu autonómne. Teológia je vo svojej podstate prepojená s Cirkvou. ${ }^{80}$ Cirkev teda nie je len predmetom teologického uvažovania, ale aj subjektom, a to vzhladom na Božie zjavenie, ktoré je podávané živou Tradíciou. ${ }^{81}$

To znamená, že teológ by mal uskutočňovat teológiu v Cirkvi v súlade $\mathrm{s}$ vierou Božieho ludu. ${ }^{82}$ Práve v kontexte Cirkvi nachádza teológia opodstatnenie svojej existencie. Ak je uskutočňovaná mimo nej, nemá žiadny význam a stáva sa len hypotézou, o ktorej je možné diskutovat, ale na ktorej nemožno založit svoj život. Žiadne teologické uvažovanie nie je možné bez osobného primknutia k viere Cirkvi. ${ }^{83}$ Cirkev a teológia sa vzájomne potrebujú, pretože „Cirkev bez teológie

\footnotetext{
Porov. Bordoni. Dal Concilio Vaticano II, s. 35-36.

Bordoni. Dal Concilio Vaticano II, s. 36.

Porov. Bordoni. Dal Concilio Vaticano II, s. 36.

Porov. Bordoni. Dal Concilio Vaticano II, s. 37.

Porov. Bordoni. La Tradizione vivente s. 74-75.

V tejto súvislosti chceme upozornit na dokument MTK Sensus fidei v životě církve z r. 2014, český preklad: Praha: Krystal OP 2015.

83 Porov. Bordoni. La Tradizione vivente, s. 76.
} 
sa ochudobňuje a stáva sa zaslepenou, teológia bez Cirkvi stráca svoju opodstatnenost" ${ }^{84}$

\section{Záver}

Bordoniho štúdia o teologickej skúsenosti v pokoncilovom období, predstavuje cenné svedectvo, ktoré poukazuje na jeho zápal a nadšenie, ale zároveň aj na jeho náročné úsilie teológa v čase obnovy teologickej metódy.

Okrem osobnej skúsenosti v nej autor tiež ponúka niekol'ko dôležitých podnetov pre teologické uvažovanie. Zvlášt môžeme podčiarknút jeho silný akcent na metafyzické predpoklady teologického uvažovania. Ide o stále aktuálnu výzvu, s ktorou nie je jednoduché sa vysporiadat' zvlášt v súčasnom období poznačenom tzv. „slabým myslením“ (pensiero debole) vo filozofii. Taktiež si môžeme všimnút jeho dôraz na vztah medzi Písmom a Tradíciou, ktorý je potrebné chápat' hermeneuticky. Na jednej strane musíme hovorit' o prvenstve Písma, na druhej strane „bez ekleziálnej tradície by bolo Písmo len mŕtvym spisom a jeho jediná funkcia, ktorú by si mohlo nárokovat by bola čisto dokumentačného charakteru“ ${ }^{85} \mathrm{~V}$ neposlednom rade nemôžeme prehliadnut Bordoniho dôraz na ekleziálny charakter teologického uvažovania. Rímsky profesor viackrát podčiarkol, že teologické uvažovanie nemôže byt' oddelené od viery teológa, ktorá ho spája s ekleziálnym spoločenstvom v ktorom žije a pôsobí. Teológia nikdy nemôže byt' vnímaná ako súkromná záležitost' jednotlivého teológa, preto aj sloboda vlastná teologickému bádaniu sa vždy uskutočňuje vo vnútri viery Cirkvi.

Tvorba M. Bordoniho je preniknutá teologickou obnovou v pokoncilovom duchu. Nestrannému čitatel'ovi by sa mohlo zdat', že hovorit’ o teologickej obnove viac ako 50 rokov po koncile je bezpredmetné. Súčasná situácia však naznačuje, že obnova dogmatickej teológie vo svetle II. vatikánskeho koncilu neprebehla v celej Cirkvi rovnako. Svedčí o tom aj vývoj dogmatickej teológie na Slovensku, kde sa obnova teológie nachádza na ceste. Tvorba M. Bordoniho môže preto byt́ pre teológiu v našich zemepisných šírkach vel'mi inšpirujúcou. Vyznačuje sa rovnováhou a odvahou. Rovnováhou, pretože Bordoni bol schopný

34 Bordoni. Dal Concilio Vaticano II, s. 38.

85 A. Vanhoye. La Parola di Dio nella vita della Chiesa, s. 33. 
načúvat' rôznym pozíciám, ktoré boli odlišné od jeho vlastnej a skôr ako vyjadril vlastný názor, snažil sa pochopit ich podstatu a motivácie. Jeho odvaha pramenila z vnútornej slobody, podporovanej silnou osobnou spiritualitou. Nemal strach z teologických výdobytkov, ku ktorým dospel na základe pozorného skúmania a rozlišovania a ktoré sa snažil postupne presadit'. Jeho zámerom bolo byt verný tradícii Cirkvi v danom ekleziálnom prostredí.

Katedra systematické teologie Cyrilometodèjská teologická fakulta Univerzity Palackého

Univerzitni 22

77111 Olomouc

E-mail:ivana.kosturova@gmail.com 